\title{
Means of Transition between the Worlds (based on English and Ukrainian Fairy Tales)
}

\author{
K. Stepanenko \\ Kyiv National Linguistic University, Kyiv, Ukraine \\ Corresponding author. E-mail: stpnnkkaterinaukkr@gmail.com
}

Paper received 05.11.19; Accepted for publication 18.11.19.

\section{https://doi.org/10.31174/SEND-Ph2019-211VII62-13}

\begin{abstract}
The article gives a thorough explanation on the nature of the fairy tale, defines the notion of the fairy-tale worlds, and provides classification of the means of transition between the worlds of the English and Ukrainian fairy tales from the semiotic perspective. The means of the transition are classified as follows: mediator, magic helper, trigger. Mediators and magic helpers are also studied from the semiotic perspective according to Ch.S.Pierce's classification of signs: symbol, index, icon. Keywords: fairy tale, fairy tale world, semiotic approach, symbols, intermediaries, mediators, magic helpers, transition between the worlds.
\end{abstract}

Introduction. Investigation of the fairy tales in the recent years has been of high interest for researchers in the fields of linguistics, sociology, psychology, philosophy, anthropology, literary and culture studies and even geography, architecture, and art in general. It is widely known that fairy tale plays a huge role in the folklore of every country. It is one of the oldest genres in literature which accumulated cultural knowledge and experience of generations. Despite the simplicity of plot and structure, fairy tale holds rich archaic beliefs and symbols that, in case the reader decodes them, can explain a lot about the culture, as well as about primitive beliefs and traditions regarding the fairy-tale worlds. In this article we are going to focus on the means, which enable the fairy tale hero to make the transition from one fairy tale world to another. Since the data of polygenetic researches prove that there have been found a lot of similarities between the tales of the world [6], we are going to illustrate it with English and Ukrainian tales, which will enable to make the paper more descriptive.

Related publications. The key figures whose studies mostly contributed to the ideas of this article include V.Propp [21] and Claude-Levi Strauss [19]. V.Propp, a famous folklorist, who identified the simplest structural units - the functions. One of these functions (a magic helper) is a key item of this paper and will be introduced further in the text. Owing to the V.Propp's "Morphology of the Fairy Tale" a number of scientists such as A Dundes [3], K.Bremon [16], K.Levi-Strauss, E.Meletinskiy [20] made a tremendous impact on the development of folklore studies in the framework of structural approach. C.Levi Strauss, a French anthropologist, who followed the principles of structuralism as well, crystalized the idea of mediators, which are also of high importance for the current paper. Since then, many scholars have studied folklore of various cultures, however the figures to be mentioned in this article are E. Meletinskiy [20], K.Bremond [16], F.Vaz da Silva [14], A.Dundes [3], Dan Fang [4], Allan B. Chinen [3], Jack Zipes [15]. The symbols inherent to different cultures, have been studied by O.Kononenko [18], N.Slukhai [22]. Although the scholars have different approaches to study of fairy tales and may disagree on the nature of symbols, they agree on the possibility of unlocking the fairy tales' symbols, and rich meanings that those symbols convey. Along with folklore and structural perspective, this paper includes the semiotic aspect, thus the Ch.S.Pierce's study on signs is highly applicable [12].

The importance of study the folktale from semiotic perspective has been highlighted by Francisco Vaz da Silva [14]: "Because the marvelous elements in fairy tales call for an explanation, a cohort of bright minds have pored over the problem of fairy-tale symbolism".

The aim of the paper. The aim of this article is to classify and illustrate the means of transition between the fairy-tale worlds within the lingo-semiotic approach. This approach involves the specification of a set of interrelated concepts, i.e. a fairy tale, a fairy tale world, the transition between the worlds, as well as the transition devices that help the actor pass from one world into another.

Material and methods. Data for this study have been taken from collections of English and Ukrainian fairy tales which are classified as "fairy-tales"," wonder tales" or "tales of magic", constituting a category of folk narrative, where objects or beings with supernatural powers are found. We analyzed the fairy texts from the viewpoint of transition devices between fairy-tale worlds, which have been classified by structural-functional criterion.

Results and their discussion. It's important to identify what a fairy tale is since this term has a number of various definitions. The Greenwood Encyclopedia of Folktales and Fairy Tales stresses the fact that the term itself is quite new (it is coined since 1697, by Marie Catherine d'Aulnoy) and has French origin. [7, p.232]. The confusion occurred with this term because it was used to identify stories with fairies, however, not every fairy-tale has fairies mentioned. Merriam-Webster Dictionary says that a fairy tale is "a story (as for children) involving fantastic forces and beings (such as fairies, wizards, and goblins)" or "a story in which improbable events lead to a happy ending" or even as a "made-up story usually designed to mislead" [10]. Jack Zipes, for instance, differentiates the terms "fairy tale" and "folk tale" as he says "In both the oral and literary traditions the tale types influenced by cultural patterns are so numerous and diverse that it is almost impossible to define a wonder folk tale or a fairy tale or explain the relationship between the two modes of communication" [15]. Cambridge Dictionary defines a fairy tale (also a "fairy story") as "a traditional story written for children that usually involves imaginary creatures and magic and also as a story that often involves imaginary creatures and magic" 
[2]. Stith Thompson points out that there is no proper term in the English language for the tales with signs of magic, even though the term "fairy tale" is widely used. And some folklorists prefer a German term Märchen or "wonder tale" to refer to the fairy tale, since, they believe, it is more substantial [13]. Thus, in this particular paper a fairy tale is denoted as a folk tale about imaginary events, heroes, worlds, and the plot of such tale involves magic items among other key elements.

However, the undeniable fact is that the background of the fairy tale is the fairy/ magic world which resembles the image of the perfect one. It is important to highlight the fact, that the distinctive characteristic of the fairy tale is the opposition and strict distinction of "this world" and "that world" [17]. The search of a different, imaginary world is the driver, that pushes the hero to fight with the difficulties. The "other world", defined also as the "alternative world" by J.Zipes [15], is not only a literary travel to another land, island, crossing a forest or a river, but often a metaphorical representation of various conditions such as birth, adulthood, marriage, death, dream, changing the status and even the dress or look of the hero/ agent. These challenges on the path are impossible to overcome without the specific helpers. The helpers can greatly vary and may be of animal or human origin, they can be plants, household items, supernatural beings, and they help to make the transition from one fairy-tale world to another. These helpers are important to classify since they signify archaic archetypical beliefs and, therefore, are culturally significant.
In this article we provide the classification for the means of transition between the fairy tale worlds as follows:

1- Mediators (non-anthropomorphic):

-objects

-actions

-notions

-events

-conditions

2- Magic helpers (may have anthropomorphic traits): -objects

-things

-supernatural beings, imaginary creatures

3- Triggers (verbal signs, sacral actions verbally represented):

a) illocutive-signs

b) illocutive-prohibitions

One of the first scientists to use the notion of mediation was C.Levi-Strauss. To illustrate this phenomenon, the researcher used rituals of passage described in myths, understood as a logical structure which enables to realize the passage from life to death, and this passage can be understood and realized through the smallest units. LeviStrauss (as well as V.Propp) focuses on simplest functions that are performed by various actors $[19$, c. 212]. He selected constituent elements and called them structural units.

The Scheme 1 shown below makes it possible to visualize this idea.

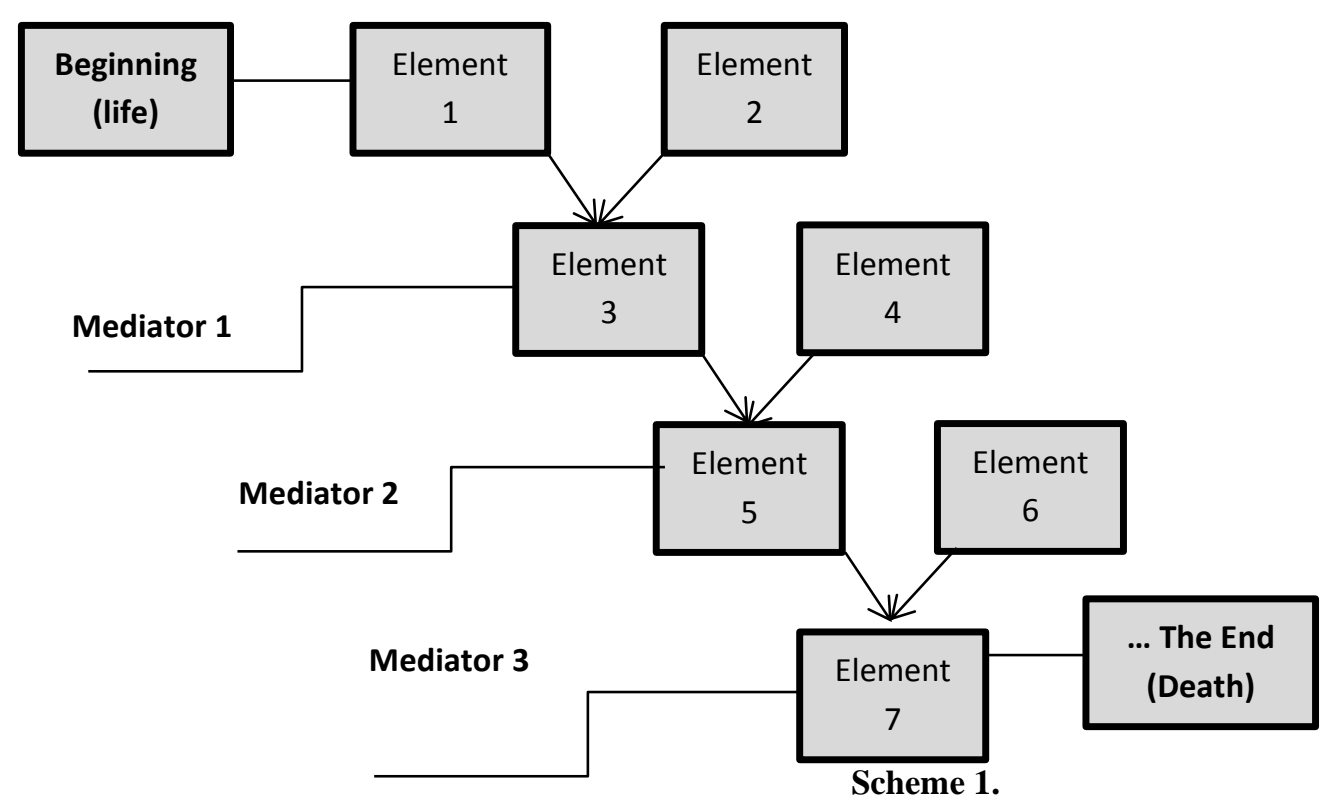

It is important to say that in Levi-Strauss's opinion myth is a combination of binary oppositions such as good-evil, up-down, life-death, light-dark. Since these elements constitute parts of the myth, they are used to soften the oppositions and this is how mediation occurs: two elements form the third element which is a mediator itself. Next, this mediator is combined with another element and they form a new element, which is again a mediator. This chain of elements-mediators is used to illus- trate the logic between the oppositions [19, c. 236] and, eventually, the passage from life to death, from one world to another.

Following on from observations, mediators are the most symbolic among means of transitions and are the most frequent evidence of symbolism in the tale narrative. Hence, we can use the classification of Ch.S.Pierce, who divided all the signs onto symbols, icons and indexes. One of the most convincing examples to be mentioned 
among mediators-symbols is Water. Drinking water (a) gives supernatural power, which is a transition from weak to strong, (b) brings back to life marking then a transition from death to life and vice versa, (c) gives new skills like understanding the language of animals which takes to the world of wisdom (Ukrainian tales "Oh", "Cane-Girl", "Youthful Water"). Water as a symbol is more typical for Ukrainian folklore. Another important example of mediators-symbols is Forest, which is significant for both Ukrainian and English fairy narrative. Alexander Porteous in the book "The Forest in Folklore and Mythology" admits that there is obvious evidence of resemblance between human life and a tree. However, in Ukrainian tales we see an unknown, no-name forest, while in English tales the forests are often given names: Forest Inglewood, Forest of Colombiers, Forest of Compaigne [11].

The iconic signs in the tales are the signs that by the way they look resemble the object they denote (the mirror resembles the river because its surface is as smooth as the surface of water, the hairbrush resembles the dense forest, the flute made of a tree branch resembles the tree).

Index denotes the object that it has cause and effect relationship with. In the narrative we research it is often shown through "a part of a whole", for example, the stump is a part of a tree, the seed is a part of a plant, fur or the skin is a part of an animal. In the "Ivasyk-Telesyk" tale, voice is a part of a human image, having heard the snake speaking with a mother's voice, the boy thought it was his mother, not the snake. One more group of things that may represent this category is personal items: leaving a personal item in this world a person has a chance to come back safely from another world as we see in Ukrainian tale "Oh": the boy changes himself into a bird or an animal but asks his father not to get rid of his hat or bridles to be able to come back and obtain a human look again. Another example is found in an English tale "Cane Girl": a book as a personal belonging of a giant if burnt makes the giant die.

Having analyzed 100 magic tales from the collection of A.Afanasiev, V.Propp made a conclusion that a narrative element can "travel" from one tale to another and the plots of the tales are tightly connected. According to V.Propp there are 31 structural elements of the fairy tale called functions, and that there are constant and variable items which can substitute each other: the names of the heroes and items change but the action they perform is the same, the heroes are of great number but the functions they performed remained limited. This discovery made V.Propp identify the well-known 31 constant functions in the tale. One of them is receiving a magical helper which can be an animal (a horse, a wolf, a bird), objects from which the agents appear (a box, a ship, a tree), objects that poses magic power (water, a sword, a hat), and magic qualities (power to change oneself into an animal). The magical agents may be given as a gift, as a reward, they may be suddenly found on the way, or they may offer help by themselves. Since we include into this group the helpers that have anthropomorphic qualities, we can find following examples: a speaking horse ("Tree to the Sky") acts like a helper taking the hero from sky to the earth. A horse's head ("Horse's Head") helps to convert into the rich if a person behaves well and follows its directions. Birds, such as three cranes, three eagles, three falcons predict the future and help to avoid death ("About a True Friend"). Additionally, something or somebody who/ that grants a magic helper can be a helper as well, for example, a witch that shows the way out of the forest (often unintentionally).

The very important, however not paid enough attention, transition element is a trigger. According to the Cambridge Dictionary, a trigger is "an event or situation, etc. that causes something to start", while for our research we identify triggers as verbal signs, sacral actions verbally represented [1]. These are the words or phrases that are recognized by an actor as a call for action or non-action, therefore, they can be of two types. First, illocutivesorders "You will catch me first" says Jack to the Giant to provoke a Giant for the fight ("Jack the Giant-Killer"), "Take my daughter as my royal decree" - an order to marry, transition to married life ("The Princess of Canterbury"), "Sit down on the brink of it (hedge) and there will come three golden heads...whatever they require, that do" - the opportunity to get heads as helpers to overcome the obstacles ("The Princess of Colchester"), "Wash me, and comb me, and lay me down softly" - the request by the head, if done - the head will cooperate and help ("The Princess of Colchester"), "I require to do what I command" - for the fairy magic not to disappear, to fight the giant ("Jack and the Bean-Stalk"), "Go along the direct road" - the direction to fight the giant ("Jack and the Bean-Stalk"), "While you do as I order you- I will protect and guard you" - the request of a fairy for her power not to disappear ("Jack and the Bean-Stalk"), "Lay!" - the request for the hen to lay golden eggs ("Jack and the Bean-Stalk"), "Play!" - the golden harp started playing ("Jack and the Bean-Stalk"), "Strike (rub) the eyes of a child with an ointment"- enables to see fairies ("The Fairy's Midwife"), "I thirst" - immediately appears a drink ("The Fairy Horn"), "Drink, give me drink! Go to hell for it if you can't get it on Earth" - direction to go to the different world ("Dando and His Dogs"), "The door, open!/ The door close!" - this order makes the heavy door leading to treasure move ("About a True Friend").

And another group is the illocutive-prohibitions: "Be bold, be bold, but not too bald" - a warning writing on the door not to enter the underground ("Mr.Fox"), "[ $[.$. The Claud Lad of Hilton will do no more good" - the house spirit was never seen again ("The Claud Lad of Hilton"), "Do not let your mother know" - for the fairy not to stop helping ("Jack and the Bean-Stalk").

Conclusion. Standard Dictionary of Folklore, Mythology and Legend says that the fairy tale is transmitted by word, by act and by symbols [9, p.20], therefore, the role of symbols should not be underestimated, and since the transition means, especially mediators, are exceptionally symbolic in the folk narrative they are among key elements for decoding multiple meanings hidden in the tale.

Mediators, helpers, and triggers are important components in the structure of fairy tales as they help to provide the transition between the fairy tale world, and perform a linking function between the other functions (elements) of the narrative. The presence of various worlds can be clearly seen in the folklore, since the search of a different world, condition, knowledge is the motivator for the hero for action, travel, a journey. The obstacles are impossible to overcome without the special devices - the means of 
transition. These devices are usually symbolic and thus are of high value for understanding the system of beliefs and values. They appear the most important stages of life and symbolize change (whether growth or decline).

According to B.Holbek [8, p.380], there is a specific pattern for remembering stories and producing new ones. This is how the similarity between the tales, motives, and function in the folklore of different countries can be explained. Fairytale as a subgroup of folklore was never created exclusively for children since it is a rich source of information, experience and frame for decision-making in unexpected situations. And the problem of the fairy tale worlds (real or metaphorical) remains among existentially-significant subjects. https://dictionary.cambridge.org/dictionary/english/trigger

2. Cambridge Dictionary. Retrieved from https://dictionary.cambridge.org/dictionary/english/fairy-tale

3. Chinen Allan B. Fairy tales and transpersonal development in later life// The Journal of Transpersonal Psychology, 1985. Vol. 17, No.2, P. 99-122.

4. Dundes A. The Meaning of Folklore. Bronner, Simon J. (Ed.)//University Press of Colorado, 2007. $580 \mathrm{p}$.

5. Fang D. Magical Objects in Victorian Literature: Enchantment, Narrative Imagination, and the Power of Things// Dissertation, Faculty of the Graduate School of Vanderbilt University, Nashville, Tennessee, 2015. 191p.

6. Graça da Silva S, Tehrani J.J. Comparative phylogenetic analyses uncover the ancient roots of Indo-European folktales// R. Soc. open sci.3: 150645. 2016. Retrieved from http://dx.doi.org/10.1098/rsos.150645

https://royalsocietypublishing.org/doi/pdf/10.1098/rsos.15064 5

7. Haase D. (Ed.) Greenwood Encyclopedia of Folktales and Fairy Tales// Greenwood Press, Vol.1 A-F, 232 p. Retrieved from

https://books.google.com.bh/books?id=Jdx2fhPM1XIC\&pg= PA323\&lpg $=$ PA323\&dq $=$ fairy + tale + definition \&source $=$ bl\&o ts=BwdZsAMVVd\&sig=ACfU3U3d7dUpxS6i2t_inINwXmFeVSX_w\&hl=en\&sa $=$ X\&ved $=2$ ahUKEwjNt8_ovpbiAhXrA WMBHX1pCmA4HhDoATAHegQICBAB\#v=onepage \&q=f airy $\% 20$ tale $\% 20$ definition $\& \mathrm{f}=$ false)

8. Holbek B., Interpretation of Fairy Tales// Helsinki: Suomalainen Tiedeakatemia. 1992: On the comparative method in folklore research. Turku: Nordic Institute of Folklore. 1986. $380 \mathrm{p}$.

9. Maria Leach (Ed.) Standard Dictionary of Folklore, Mythology and Legend// Funk \& Wagnalls; First Edition, Vol.1: A 1. P.20.
10. Merriam-Webster Dictionary. Retrieved from https://www.merriam-webster.com/dictionary/fairy-tale

11. Porteous A. The Forest in Folklore and Mythology// Dover Publications, Inc., Mineola, New York. 2002. 320 p.

12. Rossella Fabbrichesi and Susanna Marietti (Ed.) Semiotics and Philosophy in Charles Sanders Peirce// Cambridge Scholars Press, 2016. P.1-16.

13. Stith T. The Folktale// The Dryden Press, New York, 1946. P. 4.

14. Vaz da Silva F. Fairy-Tale Symbolism: An Overview// Cambridge University Press, The Cambridge Companion to Fairy Tales, 2014. P.97-116.

15. Zipes J. A fairy tale is more than just a fairy tale// Book 2.0. Vol. No. 1\&2. 2012, P.113-120.

16. Бремон К., Структурное изучение повествовательных текстов после В. Проппа// Французская семиотика: от структурализма к постструктурализму (Пер. с фр. и вступ. ст. Г.К. Косикова). - М.: Изд. Группа «Прогресс», 2000. $246 \mathrm{c}$.

17. Брицина О.Ю., Українська усна традиційна проза: питання текстології та виконавства// Київ, ІМФЕ ім. М. Т. Рильського, 2006, 397 с. http://ukrainaforever.narod.ru/ukrproza.html

18. Кононенко О. Українська міфологія. Символіка// Харків, Фоліо, 2017. 217 c.

19. Леви- Стросс К. Структурная антропология// Москва, Эксмо Пресс, 2001. 511с.

20. Мелетинский М.Е. Структурно-топологическое изучение сказки// Мелетинский М.Е. (Ред.) Структура волшебной сказки.- М.: Российск. гос. гуманит. ун-т, 2001. 234 с.

21. Пропп В. Морфология волшебной сказки// Москва, Лабиринт, 2001.257c.

22. Слухай Н. В. Лінгвістичні виміри східнослов'янського міфу:психологічні асоціативи// Актуальні проблеми української лінгвістики: теорія і практика, Київ: Київський нац. ун-т ім. Т. Шевченка, 2002. Вип.5, С. 41-52.

\section{REFERENCES}

16. Bremond C. Structural study of narrative texts after V.Propp// French semiotics: from structuralism to poststructuralism (Introductory word and translation by G.K.Kosikov). - Moscow: Publishing Group Progress, 2000. $246 \mathrm{p}$.

17. Britsyna O.Yu. Ukrainian Oral Traditional Prose: issues of Textology and Performance// Kyiv, IMFE M.T.Rylsky, 2006, $397 \mathrm{p}$.

18. Kononenko O. Ukrainian Mythology. Symbolism// Kharkiv, Folio, 2017. 217 p.

19. Levi-Strauss C. Structural Anthropology// Moscow, Eksmo Press, 2001. 511p.

20. Meletinskiy M.E. Structural-topological Study of a Tale// Meletinskiy M.E.(Ed.) Structure of a Fairy Tale, Moscow, The Russian State University for the Humanities, 2001. 234 p.

21. Propp V. Morphology of the Folktale// Moscow, Labyrinth, 2001.257p.

22. Slyhay N.V. Linguistic Dimensions of the Eastern Slavic Myth: Psychological Associations// Actual Issues of Ukrainian Linguistics: theory and Practice, Kyiv: Taras Shevchenko National University of Kyiv, 2002. Is.5, P. 41-52. 